Studies in African Linguistics

Volume 41, Number 2, 2012

\title{
Prenominal Relative Clauses in Ethiopian languages: FROM INSIDE AND FROM OUTSIDE
}

\author{
WU Tong \\ 吴桐 \\ NanKai University \\ 南开大学
}

\section{Introduction}

The Ethiopian Language Area - including Ethiopia and Eritrea, as traditionally conceived - has been the subject of many studies for more than half a century (Leslau 1945, Greenberg 1959: 24, Ferguson 1970, 1976, Heine 1975: 41, Appleyard 1989, Zarborski 1991, 2003, 2010, R. Hayward 2000, Crass 2002, Bender 2003, Bisang 2006, Crass \& Meyer 2008), in spite of recent questioning of its integrity (Tosco 2000).* Studies supporting an Ethiopian Language Area identify a number of properties shared by Ethiopian languages. ${ }^{1}$ For example, Ferguson 1976 listed 26 features, Zaborski 2003 listed 28 features, and Crass \& Meyer 2008 listed another 12 features.

This study, to some extent following the above tradition, discusses a syntactic structure until now largely neglected, i.e., prenominal relative clauses. It aims to present a synthetizing study of the structure in Ethiopian languages. The Ethiopian Language Area seems to be the only area in Africa where there is strong concentration of languages with prenominal relative clauses (Dryer 2005). Even if Wu 2011's typological study on prenominal relatives includes many prenominal-relative-clause languages, Ethiopian prenominal-relative-clause languages are poorly represented and only briefly discussed. This study can, therefore, be considered a

\footnotetext{
* I thank Hayat Omar and Chloé Darmon for having helped me with Amharic data and Jason Overfelt for Tigrigna. I also thank the Laboratoire Dynamique du Language (CNRS, UMR 5596), where part of the work was done. I am indebted also to Marc Lee and the editorial office of Studies in African Linguistics for their proofreading and stylistic improvement. My thanks also go to the editor and the anonymous reviewers of Studies in African Linguistics for their comments and suggestions. If any imperfections remain, the fault is mine.

${ }^{1}$ For simplicity's sake, I use "Ethiopian languages" to refer to languages spoken in the Ethiopian Language Area, i.e. in Ethiopia and Eritrea.
} 
study complementing Wu 2011. More importantly, as will be shown later, some of Wu 2011's conclusions are challenged if Ethiopian prenominal-relative-clause languages are taken into account. Thus, this study may not only shed new light on morphosyntactic similarity among Ethiopian languages but also deepen our understanding on prenominal relative clauses in general.

The main objective of this data-oriented study is to give a synchronic typological overview of Ethiopian prenominal relative clauses, both from the inside and from the outside By "inside", I mean to compare prenominal relative clauses in the Ethiopian area in order to show how they are different from and/or similar to each other. By "outside", I extend the comparison to beyond Ethiopian languages and include other African languages with or without prenominal relative clauses and languages from elsewhere with prenominal relative clauses. These comparisons will show to what extent Ethiopian prenominal relative clauses are typologically marked or ordinary. However, the inside comparison will be given more attention. Furthermore, synchronic comparison naturally leads us to questions concerning language evolution and language contact. These questions have always been in the center of studies of the Ethiopian Language Area and will be discussed here.

This study is organized as follows. The first section gives a general review of Ethiopian languages and Ethiopian prenominal-relative-clause languages. The second section presents in detail three features of Ethiopian prenominal relative clauses, i.e., relativizers, internal realization of the constituent relativized on, and relative verb forms. The last section discusses these three properties from synchronic and diachronic perspectives.

\section{Ethiopian prenominal-relative-clause languages}

According to Ethnologue 2009, Ethiopia has 89 languages (5 dead and 85 living, of which 65 are Afro-Asiatic, with 17 that are Nilo-Saharan, English and Ethiopian Sign Language). Eritrea, on the other hand, has only 13 languages (i.e. one dead and 12 living, of which 8 are Afro-Asiatic, 2 are Nilo-Saharan, and the others are English and Italian). Afar (Cushitic), Saho (Cushitic) and Tigrigna (Semitic) are spoken in both countries (Lewis 2009).

Among the particuliarities of Ethiopian languages, one that distinguishes them from other African languages, is the existence of prenominal relative clauses. A relative clause can be defined as a subordinate clause which shares a semantic pivot (or domain noun, following Keenan \& Comrie (1977: 63-64)) with its matrix sentence (See Vries (2002: 14), Grosu (2002: 145) and Creissels $(2005, \S 1)$ for more detailed discussion on defining relative clauses), as in the example below:

(1) the apple $[(\text { which/that }) \text { George lay on the table }]_{\text {relative clause }}$

In this example, the relative clause (which/that) George lay on the table modifies the nominal semantic pivot (the) apple in the same way an adjective does. Since it is placed after (the) 
apple, (which/that) George lay on the table is a postnomnal relative clause. A prenominal relative clause is before the semantic pivot that it modifies. Here are examples of prenominal relative clauses from Ethiopian languages:

(2) Amharic (Semitic) (Hayat Omar, personal communication):

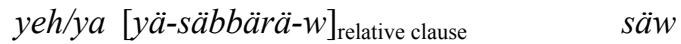
DEM REL-break.PERF.S3SG-O3SG/ART man 'the man that broke (it)'

(3) Dime (Omotic) (Seyoum 2008: 154):

[tááy Pád-déé-b-is-im $]_{\text {relative clause }}$ now come-IMPERF-REL-ART-ACC man-ART-ACC 3SG.M.SUBJ see-IMPERF-3 'He sees the man who is coming now.'

(4) Kambaata (Cushitic) (Treis 2008: 166):

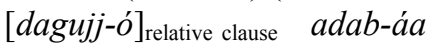
run-3M.PERF boy-M.ACC 'the boy who ran'

(5) Male (Omotic) (Amha 2001: 160):

$\begin{array}{lll}\text { Piíni } & {[\text { ziginó } \quad m u k k \text {-é }]_{\text {relative clause }}} & \text { Patsi } \\ \text { person.SG.M.NOM } & \text { yesterday come-PERF } & \text { person.M.ABS } \\ \text { zag-é-ne } & \\ \text { see-PERF-AFFIRM.DECL } & \\ \text { 'He saw the man who came yesterday.' } & \end{array}$

There are other types of relative clauses, such as correlative relative clauses, adjoined relative clauses and internally-headed relative clauses. ${ }^{2}$ Our study only concerns the prenominal relative clause, with merely very sporadic mention of other types of relative clauses. Thus, only the Ethiopian languages with prenominal relative clauses are to be discussed in detail. More precisely, only three families are concerned: Omotic, Cushitic and Semitic. Most Lowland East Cushitic languages have postnominal relative clauses (Tosco 2003: 90), for example Arbore (D. Hayward 1984, §5.7) and Tsamai (Savà 2005, §4.2). Similarly Ethiopian Nilo-Saharan languages in general do not have prenominal relatives, for

\footnotetext{
${ }^{2}$ See, inter alia, B. Downing 1978, Mallinson \& Blake 1981, §5.2, Keenan 1985, Lehmann 1986, 2003, Comrie 1989, Chapter 7, Dik 1997: vol. 2, Chapter 3, Whaley 1997: 261-262, Fabb 1999, Alexiadou et al. 2000, §3.1, Song 2001, Chapter 4, Vries 2001, 2002, 2005, Kroeger 2004, §7.2, 2005, §12.5, Creissels 2006, Chapters 32-34 and Andrews 2007 for more detailed discussion and presentation.
} 
example, Anuak (Lusted 1976: 509), Berta (Triulzi \& Bender 1976: 527), Gumuz (Bender 1979: 56), Kunama (Tucker \& Bryan 1966: 346), Kwegu (Hieda 1998: 357), Majang (Unseth 1989: 97, 106), Me'en (Will 1989: 136, 138), Murle (Lyth 1971: 7, 8, 9, 12), Nara (Thompson 1976: 493), Nuer (Crazzolara 1933: 161), Suri (Bryant 1999: 115) and Turkana (Dimmendaal 1983: 206, 308). Thus they will not be considered.

According to Dryer 2005, the prenominal relative clause is found in 7 Ethiopian languages (9 in all of Africa, including 2 non-Ethiopian languages, i.e. Ijo (Niger-Congo) (Williamson 1965) in Nigeria and Khoekhoe (Khoisan) in Namibia):

(6) Omotic (2): Gamo, Zaysete

Cushitic (2): Afar, Qimant

Semitic (3): Amharic, Chaha (dialect of Sebat Bet Gurage), Tigré

Other Ethiopian languages of the three families have recently been described as having prenominal relatives, though not all have been fully treated.

(7) Omotic (5): Dime (Seyoum 2008), Dizi (Beachy 2005), Haro (“Karo" in map 2) (Woldemariam 2004, §3.3.2.6), Male (Amha 2001), Wolaytta (R. Hayward 1993, Lamberti \& Sottile 1997, Wakasa 2008)

Cushitic (9): Alaba-K'abeena (Schneider-Blume 2007), Baiso (R. Hayward 1978, 1979), Bedawiyet (Appleyard 2007a, Musa et al. 2007, Wedekind et al. 2008), Bilen (Appleyard 2007b), Dirasha (Abire 2006), Kambaata (Treis 2008), Saho (Tosco 2003: 90), Sidamo (Anbessa 2000, Kazuhiro 2007, §5.4), Xamtanga (Appleyard 1987)

Semitic (5): Argobba (Leslau 1959, Wetter 2010), Harari (Wagner 1997), Inor (Chamora \& Hetzron 2000, §2.1.5.2.1), Silt’e (Rawda 2003), Tigrigna (Palmer 1962, Mason 1996, $\S 38$, Kogan 1997, Overfelt 2009) 


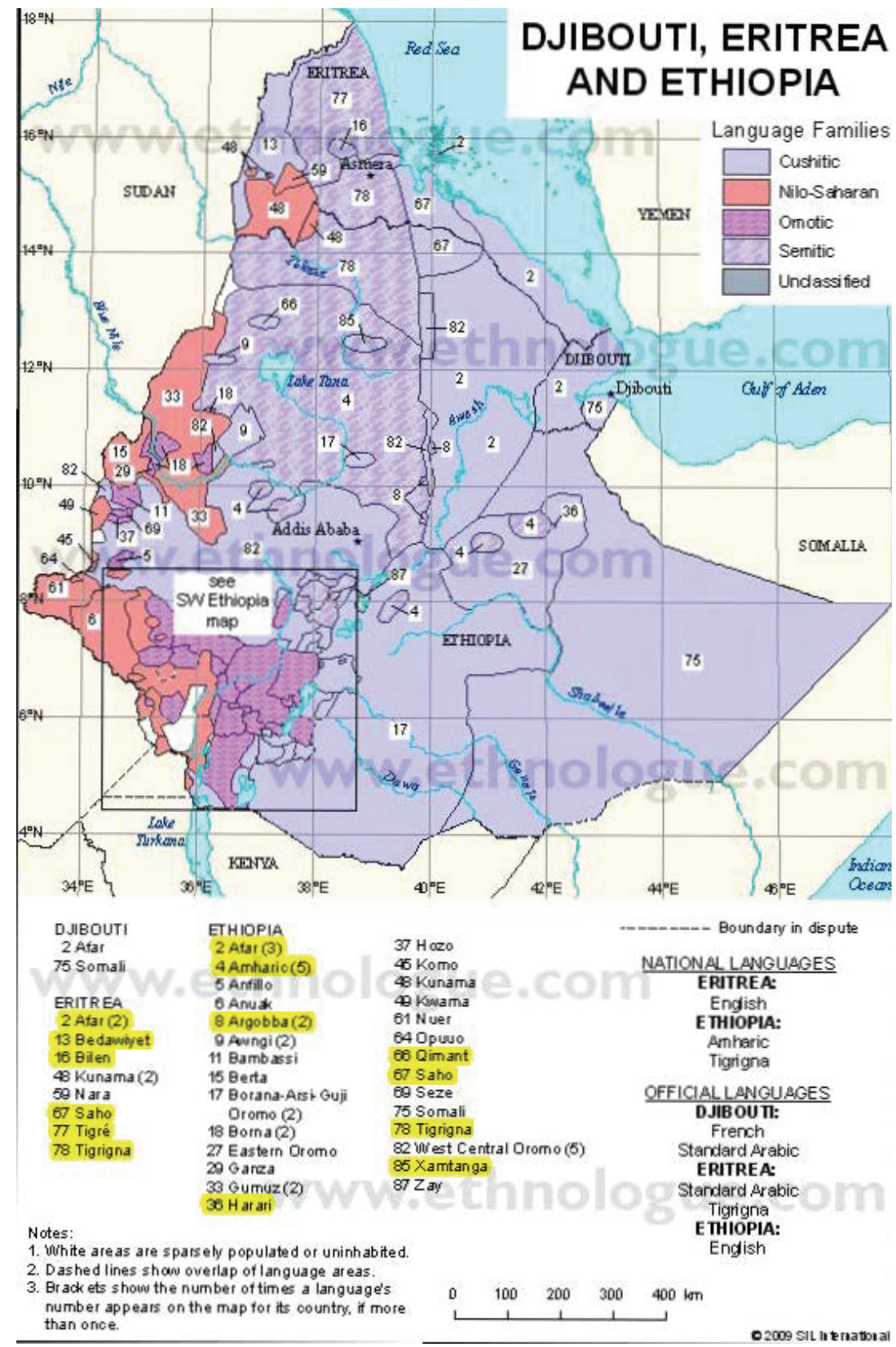

Map 1. Eritrea and Ethiopia (and Djibouti), with prenominal-relative-clause languages highlighted (from Ethnologue) 


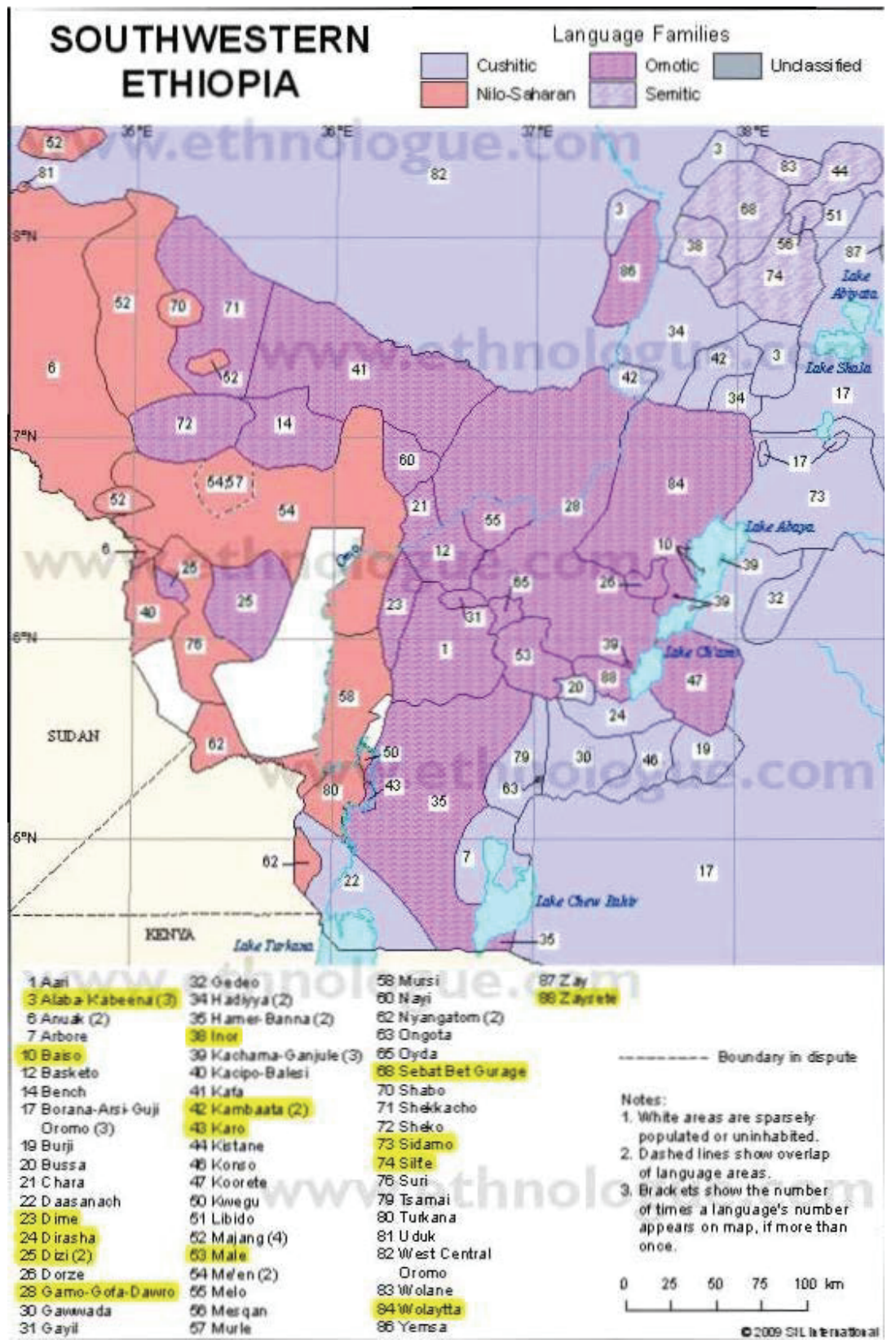

Map 2. Southwestern Ethiopia, with prenominal-relative-clause languages highlighted (from Ethnologue) 


\section{Ethiopian prenominal relative clauses}

Ethiopian prenominal relative clauses show a great degree of diversity, more than can be characterized here. I focus on three structural properties: (a) relativizers, (b) realization of the head noun in the relative clause, and (c) relative verb forms. Each property is considered from within the group of Ethiopian languages, and from outside or more typologically, i.e. compared to other African languages with or without prenominal relative clauses and to other languages from elsewhere with prenominal relatives.

\subsection{Relativizers}

A relative pronoun of the European type is not found in these languages. By "relative pronoun", I mean variable relativizers indicating the position relativized on (i.e. the case of the head noun in the relative clause). Kuteva \& Comrie (2006: 215) did not come across clear cases of relative pronouns in Africa, but Creissels (2006: vol. 2, 228) reported that Mina (Chadic) had such relativizers. The non-existence of relative pronouns in Ethiopian prenominal relative clauses follows the typological tendency that relative pronouns have never been found in prenominal relative clauses (Schwartz 1971: 144, B. Downing 1978: 392, 396, Keenan 1985: 149, Dik 1997: vol. 2, 46, Song 2001: 220, 232, Vries 2001: 235, 240, 2005: 147, Kroeger 2005: 238, Creissels 2006: vol. 2, 239, 242, Andrews 2007: 208, 218, 222, Wu 2011).

Except for relative pronouns, many other types of relativizers are used in Ethiopian prenominal relative clauses.

3.1.1 Linkers. The first type of relativizer is found, for example, in Baiso (Cushitic), Dime (Omotic) and Haro (Omotic). Following Creissels (2006: vol. 2, §33.3.4) and Creissels et al. (2008: 142), I adopt the label 'linker' (joncteur in French (Creissels 2006: vol. 2, §33.3.4)). Linkers do not indicate the position relativized on, but agree with the head noun in number, gender or noun class. More importantly, typologically, in relative clauses with relative pronouns, there can be no resumptive pronouns (i.e. pronominal elements which correspond to the head noun in the relative clause (see below)), but linkers can be used together with resumptive pronouns, for example, in Arabic (Creissels et al. 2008: 143).

$$
\begin{aligned}
& \text { ar-arzulu llaði: } \quad \text { qatalu:- } h u \\
& \text { DEF-man LINK.SG.M } \\
& \text { 'the man they killed' } \\
& \text { Lit. 'the man that one they killed him' }
\end{aligned}
$$


(9) al-bintu llati: Jahabtu maSa-ha: Pila: s-su:qi

DEF-girl LINK.SG.F go.PERF.S1SG with-3SGF to DEF-market.GEN

'the girl with whom I went to the market'

Lit. 'the girl that one I went with her to the market'

Prenominal relatives with linkers from Dime are shown in (10)-(12) (Seyoum 2008: 154, $155,156)$ :
tááy Pád-déé-b-is-im
gošt-is-im nú
yéf-déé- $n$
now come-IMPERF-LINK.SG.M-ART-ACC
man-ART-ACC 3SG.M.SUBJ
See-IMPERF-3

'He sees the man who is coming now.'

(11)
dor-ím wúdúr-in šin-i-nd
?ámz-is
lá $\chi t^{\prime}-i-n$
goat-ACC girl-DAT buy-PERF-LINK.SG.F woman-ART die-PERF-3
'The woman who bought a goat for a girl died.'
dor-is-im
wúdúr-is-in šin-i-d
Pámz-af-is
lá $\chi t^{\prime}-i-n$
goat-ART-ACC girl-ART-DAT buy-PERF-LINK.PL
woman-PL-ART die-PERF-3
'The women who bought the goat for the girl died.'

The linkers in question are $-(u) b[+$ Masculine, +Singular] as in (10), - $(i) n d[+$ Feminine, + Singular] as in (11) and -(i)d [+Plural] as in (12).

Here are Baiso examples with linkers, $k a$ [+Masculine, +Singular], ta [+Feminine, + Singular $]$ and $o$ [+Plural] (R. Hayward 1979: 116):
iso $\quad k a$
ayeeseran
hí? $i$
3PL LINK.SG.M speak.PRES.3SG language
'the language which they speak'

(14)

ker ta abate féro

dog LINK.SG.F bite.PAST.3SG finger

'the finger which the dog bit'
$\begin{array}{lll}o & \text { iminamen } & \text { keferroo } \\ \text { LINK.PL } & \text { buy.PASS.PAST.3PL } & \text { sandals }\end{array}$
'the sandals which were bought'

Different from the tripartite system in Dime and in Baiso, Haro has only two linkers, $-s a$ for masculine head nouns and -na for feminine ones (Woldemariam 2004, §3.3.2.6). 
According to Creissels (1991: 459-460) and Creissels et al. (2008: 142), linkers are common relativizers in African relative clauses. Mutaka (2000: 212) explained this phenomenon by arguing that "in languages where nouns are grouped into morphological classes, the nouns often influence the form of any noun-related element thereby ensuring a type of agreement between it (the head noun) and the noun-related element". Creissels (1991: 460) also related linkers to noun classes.

Among Ethiopian non-prenominal-relative-clause languages, Harar Oromo (Cushitic) (Owens 1985, Baye 1987) optionally marks postnominal relative clauses with linkers, xan(i) for masculine head nouns and $\tan (i)$ for feminine ones (Owens 1985: 131).

$\begin{array}{lll}\text { namicc-ii } \quad \text { (xan) } & \text { d'ufe } \\ \text { man-NOM } & \text { LINK.M } & \text { came } \\ \text { 'the man who came' } & \end{array}$

$\begin{array}{llll}\text { intal-tii } \quad \text { (tan) } & \text { innii } & \text { arke } \\ \text { girl-NOM LINK.F } & \text { 3SG.M } & \text { saw } \\ \text { 'the girl he saw' } & \end{array}$

namicc-ii (xan) intal-tii isá baréed-dúu
man-NOM LINK.M girl-NOM his pretty-F
'the man whose daughter is pretty'
Lit. 'the man that his daughter is pretty'
lamén taní-n
bite donkey-NOM two LINK.F-1SG bought 'the two donkeys I bought'

Note that there is a resumptive pronoun in (18), i.e. isá "his".

Among African languages outside the Ethiopian Language Area, Tswana (Niger-Congo) has a series of linkers (Creissels 2006: vol. 2, 212, Creissels et al. 2008: 121):

$\begin{array}{llllll}\text { monna } & \text { yo } & \text { Leburu } & \text { le } & \text { mo } & \text { rekiseditse-ng } \\ \text { man.NC1 } & \text { LINK.NC1 } & \text { Afrikaner.NC5 } & \text { S3:NC5 } & \text { O3:NC1 } & \text { sell.PERF-REL.V } \\ \text { DIKGOMO } & & & & \\ \text { cow.NC8/10 } & & & & \end{array}$

'the man to whom the Afrikaner sold cows'

Lit. 'the man that the Afrikaner sold cows to him' 
(21)

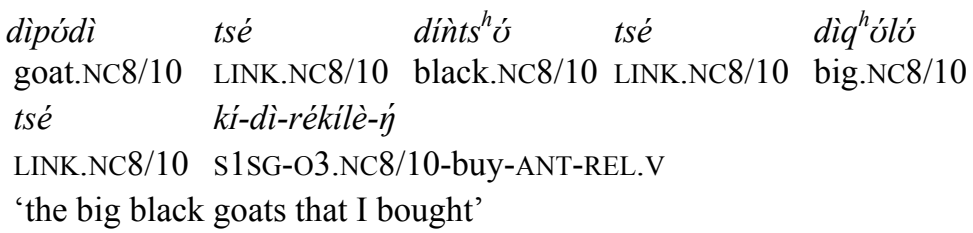

The linkers yo in (20) and tsé in (21) are marked for the noun class of the head nouns, monna 'man' in the first class and dìvúdì 'goat' in the 8/10 class. Similar to Arabic examples (8)-(9) and Harar Oromo (18), yo in (20) co-occurs with a resumptive pronoun, i.e. mo.

With regard to African relative clauses in general, Ethiopian prenominal relatives with linkers seem to be in the mainstream. However, from a typological point of view, they are very exceptional, because nowhere else similar prenominal relatives seem to have been documented. Creissels (2006: vol. 2, 240) even reported that linkers were never found in prenominal relative clauses. Wu 2011's typological study only mentioned Dime linkers. The existence of linkers in Ethiopian prenominal relatives demonstrates the conflict between regional particularity and typological tendency.

3.1.2 Complementizer. The second type of relativizer in Ethiopian prenominal relatives is complementizer. Prototypical complementizers do not vary for case - but may for other semantic features. They do not pied-pipe adpositions either. It is possible that the same complementizer can also be used in other types of subordinate clauses, such as that, used as complementizer both for relativization and for general complementation. Thus, it may be better to use "complementizer" only if the complementizer and relativizer functions overlap.

Such a complementizer is used in at least five Semitic languages, Harari, Tigré, Tigrigna, Amharic, and Argobba, which can be divided into two groups according to how T/A/M affects the complementizers.

The first group consists of Harari, Tigré and Tigrigna, where T/A/M, expressed by using an auxiliary, affects not the form of the complementizer, but its position. Tigre has the simplest pattern: the complementizer is either preverbal if there is no auxiliary, or between the main verb and the auxiliary (Palmer 1961: 24, 25):

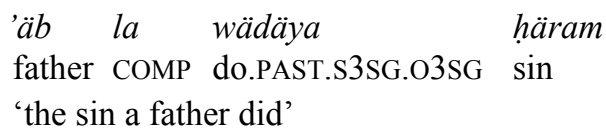

(23) la šäfättit wäddəwo la äläw ämäs

ART Shifta do.PTCPL.S3PL.O3SG COMP AUX.S3PL crime 'the crimes the Shifta were committing' 
In Tigrigna, zə- (and its allomorphs $z i-/ z \ddot{a}$-/'ว (Palmer 1962: 36)) is prefixed to the main verb without auxiliary as in (24), or to the non-gerundive main verb and the auxiliary as in (25), or only to the auxiliary if the main verb is gerundive as in (26) (Overfelt 2009: 47, Palmer 1962: 37, Overfelt 2009: 53).

Piti zi-rə?ak’’wo sab?aj

DEM.SG.M COMP-see.PERF.S1SG.O3SGM man.SG.M

'the man that I saw'

(25) 'otom 'ab'u zi-harsu zə-näbäru säb'at

DEM.PL there COMP-farm.S3PL COMP-AUX.S3PL man.PL

'the men who were farming there'

(26) Pita Piti səb?aj sənuj tsihifuwa zi-nəbərə

DEM.SG.F DEM.SG.M man.SG.M Monday write.GER.S3SGM.O3SGF COMP-AUX.S3SGM

dabdabe

letter.SG.F

'the letter that the man wrote on Monday'

In Harari (Wagner 1997: 503), z(i)- is placed before the verb in the past and in the negative past and non-past, for example zaysibar 'who does not break', but it is between the main verb and the auxiliary verb, like yisabri-z-a:l 'who breaks'.

The second group is composed of Amharic and Argobba, where T/A/M affects not the position of the complementizer, but its form: in other words, there is more than one complementizer. In Amharic $y \ddot{a}$ - as in (27) is used for perfect and $y \ddot{a}-m m-/ \partial-m m$ - as in (28) for imperfect (Hudson 1997: 482):

kä-gurage yä-tä-gän̆n̆ $\quad$ hawlt

in-Gurage COMP-PASS-find.PERF. statue

'a statue which was found in Gurage'

(28) salä-tarik yamm-i-nägər mäşəhaf

about-history COMP-S3SG-tell book

'a book which tells about history'

Argobba (Leslau 1959, Hudson 1997 and Wetter 2010) has similar complementizers. 
According to Creissels et al. (2008: 142), the use of a complementizer in relatives is common in African languages, for example, in Yoruba ${ }^{3}$ (Niger-Congo) (Lawal 1987: 69):

(29) okùnrin tí ó ra aṣo man COMP $3 \mathrm{SG}$ bought cloth 'the man who bought the cloth'

(30) aṣo tí okùnrin náà rà cloth COMP man ART bought 'the cloth that the man bought'

(31) omo tí okùnrin náà ra aso fún child COMP man ART bought cloth for 'the child that the man bought the cloth for'

and in Hausa (Chadic) (Jaggar 1998: 203, 202).

bàेkî-n dà sukà isō jiyà guests-DEF.PL COMP 3PL.FOC.PERF arrive yesterday 'the guests that arrived yesterday' $\begin{array}{llllll}g \grave{a} & m \overline{o t} \grave{a}-\tilde{r} & d \grave{a} & m u k \grave{a} & \text { sàya } & \text { jiyà } \\ \text { PRES } & \text { car-DEF.SG.F } & \text { COMP } & \text { 1PL.FOC.PERF buy } & \text { yesterday }\end{array}$ 'Here's the car that we bought yesterday.'

The complementizer is found in prenominal relative clauses in languages from all over the world, for example, -(e)n in Basque (Isolate) (Oyharçabal 2003: 764):

$\begin{array}{llll}\text { Pellok ekarri duen } & \text { dirua galdu dut } \\ \text { Peter.ERG bring AUX.COMP } & \text { money.ART } & \text { lose.PAST }\end{array}$
Peter.ERG bring AUX.COMP money.ART lose.PAST AUX 'I lost the money Peter brought.'

and de in Mandarin (Sino-Tibetan):
(35) lisi da le de na ge ren
Lisi hit $\mathrm{T} / \mathrm{A} / \mathrm{M}$ COMP DEM CL person
'the person that Lisi hit'

${ }^{3}$ According to Creissels (1991: 460), the complementizer $t i$ in Yoruba can be omitted. 
What is exceptional in Ethiopian prenominal relative clauses is the position of the complementizer. Typologically, the complementizer is often between the prenominal relative clause and the head noun, similar to the position of the complementizer in postnominal relative clauses. However, Harari, Tigré and Tigrigna complementizers are either preverbal or VP-internal and Amharic and Argobba complementizers are invariably preverbal. This is typologically marked, though not unique. ${ }^{4}$ Laze, a Kartvelian language, also has a clauseinternal complementizer (Lacroix 2009).

Another particularity of the complementizers in Amharic and in Argobba is that the aspect of the relative verb plays a role in the choice of complementizer: in Amharic y $\ddot{a}$ - for perfect and $y \ddot{a}-m m-/ a-m m$ - for imperfect; and in Argobba $i$ - for perfect and imm-for imperfect. A similar pattern is found in Tibeto-Birman languages, for example, Burmese (Herring 1991), Dolakha Newar (Genetti 2007, Chapter 17) and Kyirong Tibetan (Huber 2003).

3.1.3 Zero relativizer. Besides linkers and complementizers, a relative clause can have no relativizers at all. This 'zero marking' strategy is used, for example, in Male (Amha 2001: 160):

Piíni ziginó mukk-é Patsi zag-é-ne

person.SG.M.NOM yesterday come-PERF person.M.ABS See-PERF-AFFIRM.DECL

'He saw the man who came yesterday.'

The corresponding independent clause is (Amha 2001: 160):

Patsi ziginó mukk-é-ne

person.M.ABS yesterday come-PERF-AFFIRM.DECL

'The man came yesterday.'

Note that the only difference between the relative clause in (36) and the corresponding independent clause (37) is $-n e$, the positive declarative particle. Both clauses are aspectmarked, thus, finite. Besides -é-, other aspect-polarity markers are -á-, -andá-, -uwá- and -ibá, which are also used in relative clauses (Amha 2001: 161):

$\begin{array}{lllll}\text { gárci } & \text { Pas-á } & \text { keezz-á } & \text { miná } & \text { haiss-ó } \\ \text { old } & \text { people-NOM } & \text { tell-IMPERF } & \text { ancient } & \text { speech-ABS } \\ \text { 'stories which old people tell' } & & \end{array}$

${ }^{4}$ Some forty years ago, Hetzron (1972:41) noted that "[n]o other language has exactly the same system". 
(39)
na-att-ó-m miná haiss-ó keezz-andá na??-éll-ó child-PL-ABS-DATancient speech-ABS tell-FUT.IMPERF child-F-ABS 'the girl (i.e. female child) who will tell stories to the children'

(40)
miná haiss-ó na-att-ó-m keezz-uwá
child-PL-ABS-DAT tell-IMPERF.NEG
gabáró-ntsí
ancient speech-ABS child-PL-ABS-DATtell-
'the farmers who do not tell stories to children'

(41)
miná haiss-ó na-att-ó-m keezz-ibá gabáró-ntsí
ancient speech-ABS child-PL-ABS-DATtell-PERF.NEG farmer-DEF.PL.NOM
'the farmers who did not tell stories to children'

See Simeone-Senelle (2008) for Afar, Schneider-Blum (2007, §4.6.1) for Alaba-K'abeena, Beachy $(2005, \S 3.8 .10 .2)$ for Dizi and Kazuhiro $(2007, \S 5.4)$ for Sidamo.

Zero marking is found in other African languages, for example in Kanuri (Nilo-Saharan) (Creissels et al. 2008: 142):
kâm kasúwu-lan rúmma-dá person market-LOC see.T/A/M.S2SG-DEF 'the person you saw at the market'
(43) kâm shí-ro goro yíkána-dá person 3SG-DAT cola give.T/A/M.S1SG-DEF 'the person to whom I gave cola'

In prenominal relative clauses of languages outside Africa, many do not use relativizers at all. Such languages can be found in Asia, as in Altaic languages, e.g. Turkish (Kornfilt 1997, \$1.1.2.3) and Evenki (Nedjalkov 1997: 34), in Dravidian languages, e.g. Kannada (Sridhar 1990, §1.1.2.3), and in Indo-Aryan languages, e.g. Marathi (Pandharipande 2003, §1.1.2.3); in Europe, as in Uralic prenominal-relative-clause languages, e.g. Mari (Matsumura 1981); and in America, as in Cuzco Quechua (Lefebvre \& Muysken 1988).

3.1.4. Other cases. Some Ethiopian prenominal relative clauses can use both the complementizer and zero marking. In the Chaha dialect of Sebat Bet Gurage (Semitic) the complementizer $j a$ - is used for perfective verb stems while there is no relativizer for imperfective relative clauses (Rose 2007: 420): 
(44)
ja-čən-əč
garad
COMP-come.PERF-3SGF girl
'the girl who came'

(45)
$t i-c ̌ \partial n$
garad
3SGF-come.IMPERF girl
'the girl who comes'

For a more theoretical analysis, see Alemayehu 1990. Silt'e (Semitic) (Rawda 2003, Chapter 4) has the same pattern.

In Amharic prenominal relative clauses preceded by a preposition, $y \ddot{a}$ - and $y \ddot{a}-m m$ - are not used, so there is no overt complementizer in perfective relative clauses and there is əmmə- in imperfective relative clauses (Demeke 2001: 203):
anbäsa lä-(*yä-)-gäddäl-ä-w
lojj
lion to-COMP-kill.PERF-S3SGM-O3SGM/ART boy
'to the boy who killed a lion'
anbäsa
lä-(*yämmə-/)ammə-i-gädl-äw
lajj
lion
to-COMP-S3SGM-kill.IMPERF-O3SGM/ART
boy
'to the boy who kills/will kill a lion'

See Leslau (1959: 256) for similar phenomena in Argobba.

In the above Male examples (36), (38)-(41), repeated below, there is no relativizer:

\begin{tabular}{|c|c|c|}
\hline $\begin{array}{l}\text { Piíní ziginó } \\
\text { person.SG.M.NOM yesterday }\end{array}$ & $\begin{array}{l}\text { mukk-é } \\
\text { come-PERF }\end{array}$ & $\begin{array}{l}\text { Patsi } \quad \text { zag-é-ne } \\
\text { person.M.ABS see-PERF-AFFIRM.DECL }\end{array}$ \\
\hline
\end{tabular}

(49)

$\begin{array}{cllll}\text { gárci } & \text { Pas-á } & \text { keezz-á } & \text { miná } & \text { haiss-ó } \\ \text { old } & \text { people-NOM } & \text { tell-IMPERF } & \text { ancient } & \text { speech-ABS }\end{array}$ 'stories which old people tell'
$n a-a t t-o ́-m$
miná
haiss-ó
keezz-andá
na??-éll-ó
child-PL-ABS-DAT
ancient speech-ABS
tell-FUT.IMPERF child-F-ABS
'the girl (i.e. female child) who will tell stories to the children' 
(51) miná haiss-ó na-att-ó-m keezz-uwá gabáró-ntsí ancient speech-ABS child-PL-ABS-DATtell-IMPERF.NEG farmer-DEF.PL.NOM 'the farmers who do not tell stories to children'
miná $\quad$ haiss-ó
na-att-ó-m
keezz-ibá
gabáró-ntsí
ancient speech-ABS child-PL-ABS-DATtell-PERF.NEG farmer-DEF.PL.NOM
'the farmers who did not tell stories to children'

If the verb has no aspect markers, -ó or -oná ends the relative clause (Amha 2001: 167, 168).

$\begin{array}{lllll}\text { Piíni } & \text { waatsi gets-ó } & \text { Poti } & \text { táá-m } & \text { Ping-é-ne } \\ \text { 3SG.M.NOM } & \text { water.ABS keep-REL } & \text { pot.ABS } & \text { 1SG-DAT } & \text { give-PERF-AFFIRM.DECL }\end{array}$

'He gave me a pot in which water can be kept.'

\section{múP-óna múP?-á k'ára-ke \\ eat-REL food-NOM good-COP.AFFIRM.DECL}

'The food which we ate is good.'/ 'The food which is eaten (by us) is good.'

What is exceptional in Male relative clauses is that finite relative clauses have no relativizers while non-finite ones use the complementizers -ó or -oná. Typologically, it is often finite relative clauses that use relativizers but non-finite ones have no relativizer at all, as in English.

(55) the man that I saw yesterday

(56) the man seen by me yesterday

Wolaytta (Omotic) has a more complicated system of relativizers. The two factors that determine the use of a given relativizer are positions relativized on and aspect (Wakasa 2008: 840).

\begin{tabular}{|l|l|l|}
\hline & +subject & -subject \\
\hline imperfective & - -iya & -iyo \\
\hline perfective & - (id)a & $-($ id $) o$ \\
\hline
\end{tabular}

For examples (Wakasa 2008: 844, 845, 848, 849) 
(58) hagáá 7oott-íya bitán-iya

this.ABS do-REL.IMPERF.SUBJ man-ABS.SG.M

'the man who does this'

(59)

tam-áa-ni gaMM-ída bash-ée

fire-OBL.SG.M-in stay-REL.PERF.SUBJ griddle-NOM.SG.M

'the griddle that stayed in the fire'

(60) beett-á b-áá

be seen-REL.PERF.SUBJ thing-ABS.SG.M

'what was seen'

(61) 7i 7úy-iyo 7éess-aa

3SG.M drink-REL.IMPERF.NONSUBJ mead-ABS.SG.M

'the mead that he drinks'

(62) Tááni maTááp-aa 7imm-ido bitán-iya

1SG book-ABS.SG.M give-REL.PERF-NONSUBJ man-ABS.SG.M

'the man to whom I gave the book'

To summarize, Ethiopian relative clauses show both regional traits and typological tendencies. Linkers are exceptional world-wide, because they are unique to Ethiopian prenominal relative clauses, though they are common in Africa. As for complementizers and zero marking, Ethiopian prenominal relative clauses respect general tendencies in African languages as well as typological discoveries about prenominal relative clauses. However, what is really exceptional in Ethiopian prenominal relatives is the complexity and the diversity of relativizer systems, which Wu 2011's typological study on prenominal relatives seems to have ignored.

\subsection{Internal realization of the head noun}

In prenominal and postnominal relative clauses, which are head-external relative clauses, by definition, the head noun cannot have a full (i.e. non-reduced) nominal realization, contrary to head-internal relative clauses. In head-external relative clauses, the most frequent internal realization of the head noun is gapping, that is, the constituent relativized on is left empty in the relative clause. In most of the above examples from Ethiopian languages, there is gapping in prenominal relative clauses. Indeed, gapping is used in all the Ethiopian prenominal relative clauses, though to different extents. It is always used for subject relative 
clauses. This is also true for African languages (Kuteva \& Comrie 2006) and languages in the world in general (Keenan \& Comrie 1977, 1979).

Some Ethiopian languages consistently use gapping for objects and lower positions. See above Wolaytta examples (61) and (62) for the direct object relativization and dative relativization. Here are Male examples from objects to adjuncts (Amha 2001: 161, 165, 163):

$\begin{array}{lllll}\text { gárci } & \text { Pas-á } & \text { keezz-á } & \text { miná } & \text { haiss-ó } \\ \text { old } & \text { people-NOM } & \text { tell-IMPERF } & \text { ancient } & \text { speech-ABS } \\ \text { 'stories which old people tell' } & & \end{array}$

(64) tááni miiffe tal?-é na??-éll-á

1SG.NOM money.ABS borrow-PERF child-F-NOM

'the girl to whom I lent money' or 'the girl from whom I borrowed money'

(65) nééni waas'-ó kis's'é Pótt-éll-á

2SG.NOM water-ABS draw-PERF pot-F-NOM

'the pot with which you drew the water'

Pízi $\quad$ Pafill-ó mask-é $\quad$ wór-á
3SG.M.NOM cloth-ABS wash-PERF river-NOM
'the river in which he washed the cloth'

Other Ethiopian languages use a pronominal element - a real pronoun or cross-referencing affixes attached to the verb - in relative clauses. This pronominal element is often labeled "resumptive pronoun". According to Comrie 1981, if the pronominal element is used both in independent clauses and in relative clauses, it is not a resumptive pronoun. For example, in Hausa $y \bar{a}$ is not a resumptive pronoun, because, though used in relatives, it is also obligatory in the independent clause (Comrie 1981: 220):

(67) dōkìn dà yā mutù

horse REL 3SG died

'the horse which died'

(68) dōkì *(yā) mutù

horse 3SG died

'The horse died.'

Lit. 'Horse it died.' 
In other words, the use of $y \bar{a}$ is not due to relativization. As Comrie (1981:221) suggests, "this pronoun [i.e. $y \bar{a}$ ] functions very much like verb-agreement in European languages".

Among Ethiopian prenominal-relative languages Amharic uses resumptive pronouns - or rather, resumptive cross-referencing affixes - from direct objects to obliques (Leslau 1995: 102, 99, Hudson 1997: 482):

$\begin{array}{llll}y \ddot{a}-m a ̈ t t a-h u-t & \text { säwayye } & \text { wändamme } & n \ddot{w} w \\ \text { COMP-hit.PERF-S1SG-O3SGM } & \text { man } & \text { my-brother is }\end{array}$

'The man whom I hit is my brother.'

Lit. 'The man that I hit him is my brother.' $\begin{array}{clllll}\text { (70) wändəmmočcu } & \text { azzih } & y \ddot{a}-n a ̈ b b a ̈ r-u-t & \text { lă } & \text { tamari } & n a ̈ w \\ \text { his brothers } & \text { here } & \text { COMP-be.PERF-S3PL-ART boy } & \text { student } & \text { is }\end{array}$

'The boy whose brothers were here is a student.'

Lit. 'The boy that his brothers were here is a student.'

$\begin{array}{lll}\text { (71) Ya } & y \ddot{a} \text {-tä-wälläd-ku-bbä- } t & \text { bet } n \ddot{a} w \\ \text { DEM } & \text { COMP-MID-bear.PERF-S1SG-LOC-ART } & \text { house is }\end{array}$

'That's the house that I was born in.'

See also Silt'e (Rawda 2003, Chapter 3) for similar resumptive cross-referencing affixes. Kambaata uses resumptive cross-referencing affixes for indirect objects and lower positions (Treis 2008: 177, 179, 181).
loodáam
xa'mm-ée
meent-íchch-ut
Loodaamo.M.NOM
ask-3M.PERF.REL woman-SG-F.NOM
'the woman whom Loodaamo had asked'

(73)

harruuchch-ú-‘

argishsh-oon-sí

mánch-u

donkey.SG-M.ACC-1SG.POSS

lend-1SG.PERF-3M.OBJ.REL

person.SG-M.NOM

'the person to whom I had lent my donkey'

Lit. 'the person that I lent my donkey to him'

gízz-u mogga'-amm-o-sé mesel-éeta

money-M.NOM steal-PASS-3M.PERF-3F.OBJ.REL girl-F.ACC

'the girl from whom money had been stolen'

Lit. 'the girl that money had been stolen from her' 
(80) ise

$$
\text { hiikk'-i-t-ino t'arap'eessá }
$$

3SG.F.NOM break-EPEN-3SG.F-PRES.PERF.3 table.ACC

'the table she broke'

(81)

bule lekká hikk'-i-t-ino t'arap'eessá

Bule.NOM.F leg.OBL break-EPEN-3SG.F-PRES.PERF.3 table.ACC

'the table whose leg Bule broke'

Lit. 'the table Bule broke the leg'

$\begin{array}{lll}\text { ise } & e^{\prime}-{ }^{\prime}-\text { ino } & \text { min } \\ \text { 3SG.F.NOM } & \text { enter-3SG.F-PRES.PERF.3 house }\end{array}$

'the house into which she entered'

Lit. 'the house she entered'

(83) isi

$\begin{array}{ll}\text { isi } \quad k u b b-\varnothing-i n o & \text { hakk'iččo } \\ \text { 3SG.M.NOM jump-3SG.M-PRES.PERF.3 } & \text { tree.GEN.F } \\ \text { 'the tree from which he jumped' } & \end{array}$

Lit. 'the tree he jumped'

In Alaba-K'abeena, there is a resumptive pronoun only if the head noun is genitive in the relative clause (Schneider-Blum 2007:367):

$$
\begin{aligned}
& \text { Pam-ás(i) giddan-u wokt-í } \\
& \text { mother-SG.F.NOM.PC.3SG.M near-A/N time-TN.M.ABS } \\
& \text { reh-too-si c'úul-(u) } \\
& \text { die-3SG.F/3PL.PERF-PC.3SG.M.REL child-SG.M.NOM } \\
& \text { 'the boy, whose mother had died recently' } \\
& \text { Lit. 'the boy, that his mother had died recently' }
\end{aligned}
$$

The resumptive pronoun, i.e. -ás(i) in (84), is obligatory. On the contrary, in an NP, if the possessor is nominal, there can be dependent-marking, as in (85), or double-marking as in (86) (Schneider-Blum 2007:172):

$$
\begin{aligned}
& \text { fePleecci } \quad \text { mat-i lokk-á(i) } \\
& \text { goal.s1.M.GEN one-F.A/N leg-TN.F.NOM } \\
& \text { 'one of the billy goat's legs' }
\end{aligned}
$$


(86)

$\begin{array}{lll}\text { fePleecci } \quad \text { mat-i } & \text { lokk-ás(i) } \\ \text { goal.s1.M.GEN } & \text { one-F.A/N } & \text { leg-TN.F.A/N.PC.3SG.M } \\ \text { 'one of the billy goat's legs' } & \end{array}$

In African languages, resumptive pronouns are not rare in relative clauses. Some use resumptive pronouns even for subjecs: Kuteva \& Comrie 2006 listed four such languages: Babungo (Niger-Congo), Koszime (Niger-Congo), Ngemba (Niger-Congo) and Yoruba. From a regional viewpoint, given that resumptive pronouns are quite common in African languages, Ethiopian prenominal relative clauses follow the mainstream. However, they do challenge the long-established statement that prenominal relative clauses rarely use resumptive pronouns (Keenan 1985: 148-149, Lehmann 1986: 675, 2003: 461, Dik 1997: vol. 2, 46, Song 2001: 218, 232, Vries 2001: 235, 240, 2002: 50, 2005: 147, Kroeger 2005: 238, Creissels 2006: vol. $2,239,242)$. According to $\mathrm{Wu} 2011$, resumptive pronouns are found in more languages with prenominal relatives than previously described. However, he mentioned only Semitic languages among Ethiopian prenominal-relative languages.

\subsection{Relative verb forms}

In relative clauses, some languages use particular verbal forms different from those used as predicates in independent clauses, for example, participles in English:

(87) the man sitting on the floor

(88) the man wounded by a tiger

Some Ethiopian languages do not use special verb forms in prenominal relative clauses, like Alaba-K'abeena (Schneider-Blume 2007, §4.6.1), Amharic (Leslau 1995: 81-118), Harari (Wagner 1997), Sidamo (Kazuhiro 2007), Silt'e (Rawda 2003, Chapter 4) and Tigrigna (Palmer 1962, Kogan 1997, Overfelt 2009).

Ethiopian prenominal relative clauses with special verb forms can be classified into three prototypes:

(89) $\mathrm{T} / \mathrm{A} / \mathrm{M}$ reduction

polarity-based: positive vs. negative

position-based: subject vs. non-subject

Generally speaking, special relative verb forms are particularly common in African languages (Creissels 1991: 461, Watters 2000: 227, Creissels et al. 2008: 141). The three patterns found in Ethiopian prenominal relatives are also found in other African languages. 
3.3.1 T/A/M reduction. In the first type, there is reduction, even total absence, of $\mathrm{T} / \mathrm{A} / \mathrm{M}$ markers, for example, in Dizi (Beachy 2005: 125, 129):

(90) dadu tamir-s-da-z/-jn

child learn-CAUS-REL-M/F

'the one who causes a child to learn', i.e. teacher

(91) $\quad a: j \quad g a b-i-z$

water create-EPEN-M

'the one who creates water'

and in Male (Amha 2001: 167, 168):

Píní waatsi gets-ó Poti táá-m Ping-é-ne

3SG.M.NOM water.ABS keep-REL pot.ABS 1SG-DAT give-PERF-AFFIRM.DECL

'He gave me a pot in which water can be kept.'

(93) múr-óna mú?P-á k'ára-ke

eat-REL food-NOM good-COP.AFFIRM.DECL

'The food which we ate is good.'/ 'The food which is eaten (by us) is good.'

Note that these two languages have prenominal relative clauses with fully-conjugated verb forms, for example in Dizi (Beachy 2005: 127, 129, 131):

(94) bolim-ki-d-a

be demolished-PERF-REL-DEF

'the one that has been demolished'

(95) at jet-i-k nogim-da-d-a

now 2SG-EPEN-INSTR converse-IMPERF-REL-DEF

'the one who is conversing with you'

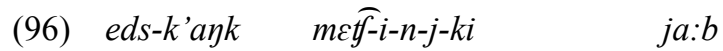

AIDS-INSTR grab-EPEN-PASS-PERF person

'the person who has been grabbed by AIDS'

$$
\begin{array}{ll}
i-k o t-n-d \varepsilon-k i & j a: b-e-n \\
\text { 3SG.F-wait-PASS-IMPERF-PERF } & \text { person-DEF-M } \\
\text { 'the lady who was being waited for' }
\end{array}
$$


The same T/A/M markers are used in Dizi independent clauses, too (Beachy 2005, §3.8.3.2). See above (36)-(41) for Male prenominal relative clauses with fully-conjugated verb forms.

Haro also has reduced prenominal relative clauses where there is neither agreement nor tense-aspect markers, but the positive particle -é- is kept (Woldemariam 2004: 104):

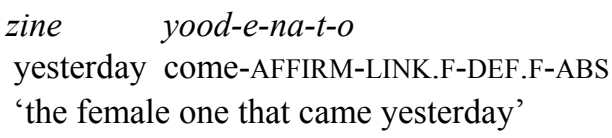

If the head noun is a man, yood-e-sa-t-o is used: $-s a$-, LINK.M replaces $-n a$-. If the relative clause is negative, - $e$ - is replaced by the negative particle -á-, used also in independent negative sentences (Woldemariam 2004: 150).

$\mathrm{T} / \mathrm{A} / \mathrm{M}$ reduction seems rare in relatives among African languages in general (Denis Creissels, personal communication). On the contrary, many prenominal relative clauses use non-finite verb forms (i.e. forms with fewer T/A/M distinctions). This is one of the most recurrent statements about prenominal relative clauses (B. Downing 1978: 392, Mallinson \& Blake 1981: 298, Keenan 1985: 160, Lehmann 1986: 672, 2003: 461, Dik 1997: vol. 2, 55-58, Song 2001: 233, Vries 2001: 235, 2002: 39, Creissels 2006: vol. 2, 239, Andrews 2007: 208). However, relative clauses in Haro are quite exceptional in that they lose agreement and tenseaspect markers but keeps the sentence particles, $-\dot{e}-/-\dot{a}$-. In other prenominal relative clauses, it is rather the sentence particles that are lost. In Korean, independent clauses have sentence particles of one of the following types: declarative, interrogative, propositive and imperative (Sohn 1999, §9.2.1), but relative clauses have only the relativizer -(u)n (Sohn 1999, §9.4.3).

3.3.2 Polarity-based. The second type of special verb forms, i.e. the polarity-based type, has three sub-types:

(99) Special positive verb forms Special negative verb forms

Special positive and negative verb forms

Qimant (Cushitic) illustrates the first sub-type. Qimant positive relative clauses have special verb forms depending on whether the position relativized on is subject or non-subject (see below) while negative relative verb forms are the same as main verb forms (Appleyard 1975: 337-339).

Afar belongs to the second sub-type. In independent clauses, the negation is marked by the stressed prefix ma- (Bliese 1981: 84): 
(100) soo'l-e 'w-aa-m 'ma-fa'd-a

stand-INF NEG-1SG.PERF-NOM NEG-want-1SG.PERF

'I don't want to stand.'

Negation in relative clauses (and in other subordinate clauses) is expressed by the auxiliary waa (inaccusative)/wee (accusative) (Simeone-Senelle 2008: 5):

(101) úrru-l tú baahé wayta lee

children-on unit bring AUX.NEG.INACC.3SG.F water

'the water that brings nothing to children'

(102) biyaakitaksugé-wee idaltí

be ill.PTCPL-AUX.NEG.ACC.3SG.M aged person

'the old person that was not ill'

Baiso also has special negative relative verb forms for the past tense and the imperfect aspect: invariable verb stem + u/annu, for example (R. Hayward 1979: 116).

(103) $\mathrm{ka}$ aman-u ibaaddooti

LINK.M.SG believe-NEG.PAST man

'the man who did not believe'

(104) $t a$ keen-annu heléeltit

LINK.F.SG bring-NEG.IMPERF woman

'the woman who does not bring'

(105) 0
keen-u/-annu
ibaaddo
LINK.PL
bring-NEG.PAST/-NEG.IMPERF
people
'people who did/does not bring'

There is another pattern of negative imperfective relative clauses in Baiso, i.e. verb stem + ( $n) u+$ LINK + giran. Giran inflects for the full concord set, for example, anfe- $u$ o giran bekke 'water which has not boiled' (R. Hayward 1979: 116). Note that negation in declarative clauses is expressed by two preverbal particles, lakko and la (R. Hayward 1978: 555).

Kambaata uses the third sub-type. In independent clauses, the accent is always on a nonfinal position in the verb (Treis 2008: 166): 
(106) adab-óo dagújj-o.

boy-M.NOM rUn-3M.PERF

'The boy ran.'

In positive relative clauses, the accent is always on the final position, thus different from independent clauses (Treis 2008: 166):

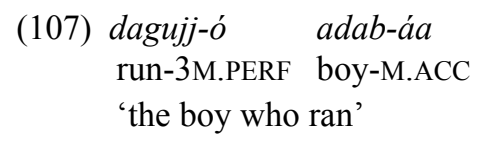

In negative relative clauses, - $u m b$ expresses negation (Treis 2008: 172):
(108)
$\begin{array}{ll}\text { mogga'-úmb-ut } & \text { óos-ut } \\ \text { steal-REL.NEG-F.NOM } & \text { children-F.NOM }\end{array}$
'children who do not steal/have not stolen/are not stealing'

This relative negation morpheme $-u m b$ is different from all other negative morphemes: $-b a{ }^{\prime} a$ for negative indicative imperfective main verbs, -im for negative indicative perfective and progressive main verbs, $-u$ 'nna for negative converbs, $-k a$ for negative jussive verbs and $-o o t$ for negative imperative verbs. Note also that negative relative verbs have the same accent pattern as adjectives, for example, muccúr-u 'clean-NOM', muccur-ú 'clean-ACC' vs. it-úmb-u 'eat-REL.NEG-NOM', it-umb-ú 'eat-REL.NEG-ACC' (Treis 2008: 170). It can be seen that in negative relatives the accent is not necessarily on the final syllable of relative verbs.

Some African languages also use polarity-based special verb forms. In Efik (NigerCongo), relative clauses are normally introduced by one of the complementizers emi/cke. Positive relative verbs have the suffix -de, for example, cke di-de 'who came' (Welmers 1973: 432). Negative relative verbs do not have the suffix -de, but use special person markers for the negative auxiliary, for example, $m m i$ - for $3^{\text {rd }}$ persons, instead of the expected $* i m a$ - or *imi-, as in emi mmi-ike di-ge 'who didn't come' (Welmers 1973: 434). On the contrary, polarity rarely, if ever, plays a role in non-Ethiopian prenominal relative clauses: $\mathrm{Wu} 2011$ did not mention any such languages.

3.3.3 Position-based. The third major type of Ethiopian prenominal relative clauses uses special verb forms according to the position relativized on, often subject vs. non-subject.

Qimant and Xamtanga use two series of relative verbs: subject forms and oblique (i.e. non-subject) forms. Polarity plays a role, too. According to Appleyard (1975: 337-339), in Qimant positive subject relative clauses, the $1^{\text {st }}$ and $2^{\text {nd }}$ persons have only the masculine marker in singular and no gender marker in plural; the $3^{\text {rd }}$ persons have gender and number 
markers, but no personal marker. In positive oblique relative clauses, the $1^{\text {st }}$ and $2^{\text {nd }}$ persons have gender and number markers with an optional additional - $\partial r$ marker, but no personal marker; the $3^{\text {rd }}$ persons have gender, number and personal markers. Negative relative verb forms are the same as main verb forms. In Xamtanga (Appleyard 1987: 483-486), positive relative verb forms have no tense/aspect marker. Subject forms have person and number markers for the $1^{\text {st }}$ and $2^{\text {nd }}$ persons and only gender markers for the $3^{\text {rd }}$ persons. Oblique forms have person markers followed by gender markers agreeing with the head noun. Negative relative verb forms show aspect differences and are almost same as main verb forms except for negative subject forms, which lack the enclitic -im. See also Appleyard (2007a: 474) and Wedekink et al. (2008, §455-484) for Bedawiyet (Cushitic), and Appleyard (2007b, §3.6.2) for Bilen (Cushitic).

Other African languages also use special verb forms according to the position relativized on. This is true for Bantu languages in particular. In the literature a distinction is often made between subject (or direct) relative clauses and non-subject (or indirect) relative clauses (Doke 1954, Zeller 2004, Henderson 2007, Letsholo 2009, L. Downing et al. 2010).

Among prenominal-relative languages, Turkic languages and Quechuan languages use different verb forms according to the diachonomy subject vs. non-subject. For example, in Cuzco Quechua, the $-q$-marked form is used in subject relatives and the -sqa-/-na-marked forms (with possessive markers) in non-subject ones (Lefebvre \& Muysken 1988:166-167):

(109) hamu-sha-q runa
come-PROG-GEN man

'the man who is coming'
(110) riku-sqa-y warma
see-PTCPL-1SG.POSS girl
'the girl that I saw'

(111) paqarin rima-na-yki runa

tomorrow speak-PTCPL-2SG.POSS man

'the man that you will be speaking to tomorrow'

See Kornfilt (1997, §1.1.2.3) for similar structures in Turkish.

\subsection{Summary}

The above presentation shows that Ethiopian prenominal-relative languages exhibit great diversity and complexity, seen from inside, among the languages themselves, and from outside, typologically. 
Seen from inside, there are three types of relativizers, i.e. linkers, complementizers and zero marking; two kinds of internal realization of the head noun in the relative clause, i.e. gapping and resumption; and three types of relative verb forms, i.e. T/A/M reduction, polarity-based and position-based. There can be even finer distinctions within one category: the polarity-based relative verb forms can be divided into three sub-groups: special positive verb forms, special negative verb forms and special positive and negative verb forms.

Seen from outside, the diversity and complexity of Ethiopian prenominal relatives can also be found in other African languages: linkers seem to exist only in African languages, and polarity-based relative verb forms are another characteristic of African relatives. However, relatives with these particuliarities in other languages are almost all postnominal. It is only in the Ethiopian Language Area that so many languages with prenominal relatives are found. Ethiopian prenominal relatives differ from prenominal relatives in non-African languages to a great extent: as seen in the comparison of prenominal in $\mathrm{Wu} 2011$, Ethiopian prenominal relatives are the only prenominal relatives which use linkers and polarity-based relative verb forms. The massive use of resumptive pronouns in Ethiopian prenominal relatives also challenges the traditional generalization that resumption is rare in prenominal relatives.

The best words to charactize Ethiopian prenominal relatives, then, are diversity and complexity.

\section{Language contact and language evolution}

Given the diversity and complexity of Ethiopian prenominal relatives, one question, among many others, is worth asking: are Ethiopian prenominal relative clauses more similar to African relative clauses or to other prenominal relatives? In other words, which factors play a more important role in Ethiopian prenominal relativization: regional factors or typological ones?

On the one hand, certain properties, such as linkers and polarity-based relative verb forms, bring Ethiopian prenominal relatives closer to African relative clauses. However, other properties differentiate Ethiopian prenominal relatives from African relatives, especially in that Ethiopian relatives are prenominal, contrary to the location of relative clauses in almost all other documented African languages. Thus it seems that Ethiopian prenominal relatives share properties both with African relative clauses and other prenominal relative clauses, and meanwhile differ from African relative clauses and non-Ethiopian prenominal relatives. All these may be better considered from a diachronic point of view.

It is well-known that languages never change in a haphazard manner in the long term. Otherwise, theories of grammaticalization would not have been possible and there would not be common patterns of cross-linguistic grammaticalization. Languages in a language area are isolated to the extent that the pressure from language contact is so strong that even linguistic universals may have to yield. Nonetheless, given that languages are part of human cognition, language universals reflect the cognitive system common to all humans. Thus pressure from 
language contact - regional factors - and human cognition - typological factors - surfaces as conflict between regional traits and typology. In my opinion, it is impossible to foresee which structural properties can surface under language contact and through language evolution. Analysis on given structural features can be undertaken only on a case-by-case basis.

The first concern is the prenominal position of Ethiopian relatives. It has been almost universally accepted that Ethiopic Semitic languages have undergone extensive influence from Cushitic (Leslau 1945, 1952, Bach 1970, Little 1974, Thomason \& Kaufman 1988: 133135, Tosco 2000). Word order change is one of the contact-induced changes and one of the easiest structural properties to borrow (Thomason \& Kaufman 1988: 88, Thomason 2001: 6971, Winford 2003). Leslau 1945 included the word order [relative-noun] in Amharic as a contact-induced change from Cushitic. Givón 1971 also argued in favor of the historical change in syntax [noun-modifier] $\rightarrow$ [modifier-noun]. The question still remains whether the appearance of prenominal relative clauses in Ethiopic Semitic languages can be due to direct borrowing or later evolution.

The hypothesis of later evolution after the appearance of OV order is attractive, but problematic, because what is typologically valid is prenominal relative clause $\rightarrow \mathrm{OV}$, but not *OV $\rightarrow$ prenominal relatives ("unidirectional correlation" in Dryer (2007: 96)): according to the statistics of WALS, out of 691 languages, 109 (i.e. 15.77\%) have OV and prenominal relatives and 96 (i.e. 13.89\%) have OV and postnominal relatives; and out of 638 languages, 92 (i.e. 14.42\%) have OV and prenominal relatives and 72 (i.e. $11.29 \%$ ) have OV and postnominal relatives. The difference (i.e. $15.77 \%$ vs. $13.89 \%$, and $14.42 \%$ vs. $11.29 \%$ ) is not statistically significant. Languages with OV order have almost the same probability of having prenominal relatives or postnominal relatives. In other words, a language could quite preserve its [noun-relative] order (i.e. postnominal relatives) even after having adopted OV from other languages. Furthermore, not all Cushitic languages have the [relative-noun] order (i.e. prenominal relatives), because most of the East Cushitic languages use postnominal modifiers in general (Tosco 2003: 90). For example, Arbore (D. Hayward 1984, §5.7) and Tsamai (Savà $2005, \S 4.2$ ) have only postnominal relative clauses in spite of their OV order. It is possible that the Highland East Cushitic group may have played a more important role in this word order change (Tosco 1994: 416), because prenominal relative clauses are found in Highland East Cushitic group in general while the Lowland East Cushitic group has almost exclusively postnominal relatives, except Afar (Simeone-Senell 2008) and Baiso (Tosco 1994: 429) in Ethiopia, and Saho in Etitrea (Tosco 2003: 90). Tosco (1994: 426) suggests that the prenominalization of relative clauses in East Cushitic languages resulted from the grammaticalization of a cleft construction where the copula was reinterpreted as an agreement marker.

The same evolution might have happened in Ethiopic Semitic languages. Possibly, Omotic languages have also influenced Ethiopic Semitic languages, because Omotic languages have a 
more thorough-going verb-final pattern than Semitic languages (R. Hayward 2003: 244) ${ }^{5}$. It may not be impossible that prenominalization of relatives may have been only an indirect contact-induced change, that is, OV order was adopted first and triggered other word-order changes, which later triggered relative-noun order change. Once more, it seems difficult to find factual arguments in favor of or against this hypothesis.

Besides the question of prenominalization of relative clauses, the origin of relativizers (i.e. linkers, complementizers and zero marking) and the origin of relative verb forms are also interesting questions, though much less studied. One may assume that Baiso, Dime and Haro linkers result from language contact, but the opposite hypothesis, i.e. the one of genetic heritage, is also reasonable. Only linguistic data, which are quite sparse on Ethiopian languages, will serve to decide the issue. Geography, history and demography must also be taken into consideration. These approaches go beyond the scope of this study, and thus cannot be developed further here. It is difficult to retrace diachronic evolution of structural properties. More importantly, structural features can be transferred from one language to another through language contact. Little's (1974: 267) remark seems still to hold: "[t]he precise source of the Cushitic influence is still very much in question and will probably remain so since very little information is available concerning the linguistic geography of ancient Ethiopia".

\section{Conclusion}

This study concentrated on three features of prenominal relative clauses in Ethiopian languages: types of relativizers, internal realization of the head noun and relative verb forms. The presentation on each point led us recurrently to the conclusion of the tension between regionalism and typology. Diachronically speaking, this situation is largely due to language contact and grammaticalization. However, it was also shown how difficult it is to track down structural properties to their origins. Future studies on historical documents and description on other less known languages may shed light on these unanswered questions.

\footnotetext{
${ }^{5}$ The substratum may be Omotic, if one attempts "to speculate about the cause of the [Highland East Cushitic] word order shift, ... [i.e.,] contact from the neighboring rigid SOV Omotic languages" (Tosco 1994: 437).
} 


\section{Abbreviations}

$1,2,3, \ldots:$ noun class (after NC)

1: first person

2: second person

3: third person

$\mathrm{A} / \mathrm{N}$ : absolutive/nominative

ABS: absolutive

ACC: accusative

AFFIRM: affirmative

ANT: anterior

ART: article

AUX: auxiliary

CAUS: causative

CL: classifier

COMP: complementizer

COP: copula

DAT: dative

DECL: declarative

DEF: definite

DEM: demonstrative

EPEN: epenthetic vowel

ERG: ergative

$\mathrm{F}$ : feminine

FOC: focus

FUT: future tense

GEN: genitive

GER: gerund

IMPERF: imperfect(ive)

INACC: inaccusative

INF: infinitive

INSTR: instrumental
LINK: linker

LOC: locative

M: masculine

MID: middle voice

NC: noun class

NEG: negative

NOM: nominative

NONSUBJ: non-subject

O1(SG)(F): object first person (singular) (feminine)

OBJ: object

OBL: oblique

PASS: passive

PAST: past tense

PC: personal clitic

PERF: perfect(ive)

PL: plural

POSS: possessive

PRES: present tense

PROG: progressive

PTCPL: participle

REL.V: relative verb form

REL: relativizer

S1(SG)(F): subject first person (singular)

(feminine)

SG: singular

SUBJ: subject

T/A/M: tense-aspect-mood

$\mathrm{TN}$ : transnumeral

\section{References}

Abire, Wondwosen Tesfaye. 2006. Aspects of Diraytata morphology and syntax: a lexicalfunctional grammar approach. Trondheim: University of Trondheim doctoral thesis. 
Alemayehu, Abebe. 1990. Relative clauses in Chaha: a GB approach. Addis Ababa: Addis Ababa University master dissertation.

Alexiadou, Artemis, Paul Law, André Meinunger \& Chris Wilder. 2000. Introduction. In Artemis Alexiadou, Paul Law, André Meinunger \& Chris Wilder (eds.), The syntax of relative clauses, 1-51. Amsterdam \& Philadelphia: John Benjamins.

Amha, Azeb. 2001. The Maale language. Leiden: Research School of Asian, African and Amerindian Studies, Universiteit Leiden.

Anbessa, Teferra. 2000. A grammar of Sidaama. Jerusalem: The Hebrew University doctoral dissertation.

Andrews, Avery. 2007. Relative clauses. In Timothy Shopen (ed.), Language typology and syntactic description. 3 vols. 2nd edn. Vol. 2, 206-236. Cambridge: Cambridge University Press.

Appleyard, David. 1975. A descriptive outline of Kemant. Bulletin of the School of Oriental and African Studies 38(2). 316-350.

Appleyard, David. 1987. A grammatical sketch of Khamtanga -- II. Bulletin of the School of Oriental and African Studies 50(3). 470-507.

Appleyard, David. 1989. The relative verb in focus constructions: an Ethiopian areal feature. Journal of Semitic Studies 34(2). 291-305.

Appleyard, David. 2007a. Beja Morphology. In Alan Kaye (ed.), Morphologies of Asia and Africa, 447-479. Winona Lake, IN: Eisenbraums.

Appleyard, David. 2007b. Bilin Morphology. In Alan Kaye (ed.), Morphologies of Asia and Africa, 481-504. Winona Lake, IN: Eisenbraums.

Bach, Emmon. 1970. Is Amharic an SOV Language? Journal of Ethiopian Studies 8. 9-20.

Baye, Yimam. 1987. Relative clauses in Oromo. Journal of Ethiopian Studies 20. 60-74.

Beachy, Marvin. 2005. An overview of Central Dizin phonology and morphology. Arlington: The University of Texas master dissertation.

Bender, Lionel. 1979. Gumuz: a sketch of grammar and lexicon. Afrika und Übersee 62. 3869.

Bender, Lionel. 2003. Northeast Africa, a case study in genetic and areal linguistics. Annual Publication in African linguistics 1. 23-46.

Bisang, Walter. 2006. Linguistic areas, language contact and typology: some implications from the case of Ethiopia as a linguistic area. In Yaron Matras, April McMahon \& Nigel Vincent (eds.), Linguistic areas: Convergence in historical and typological perspective, 75-98. Hampshire: Palgrave MacMillan.

Bliese, Loren. 1981. A generative grammar of Afar. Dallas: SIL.

Bryant, Michael. 1999. Aspects of Tirmaga grammar. Arlington: University of Texas doctoral dissertation.

Chamora, Berhanu \& Robert Hetzron. 2000. Inor. Munich: Lincom Europa. 
Comrie, Bernard. 1981. The formation of relative clause. In Barbara Lloyd \& John Gay (eds.), Universals of human thought: some African evidence, 215-233. Cambridge: Cambridge University Press.

Comrie, Bernard. 1989. Language universals and linguistic typology. 2nd edn. Oxford: Blackwell.

Crass, Joachim. 2002. Ejectives and pharyngeal fricatives: two features of the Ethiopian language area. In Baye Yimam et al. (ed.), Ethiopian studies at the end of the second millennium. Proceedings of the 14th International conference of Ethiopian studies, November 6-11, 2000, Addis Ababa, 1679-1691. Addis Ababa: Institute of Ethiopian Studies.

Crass, Joachim \& Ronny Meyer. 2008. Ethiopia. In Bernd Heine \& Derek Nurse (eds.) A linguistic geography of Africa, 228-249. Cambridge: Cambridge University Press.

Crazzolara, Joseph. 1933. Outlines of a Nuer grammar. Vienna: Anthropos.

Creissels, Denis. 1991. Description des langues négro-africaines et théorie syntaxique. Grenoble: Editions Littéraires et Linguistiques de l'Université de Grenoble.

Creissels, Denis. 2005. Typologie de la relativisation et données de l'aire Caucase-IranAnatolie. Paper read at the Atelier de syntaxe arménienne, Pithiviers 23-25 May.

Creissels, Denis. 2006. Syntaxe générale: une introduction typologique. 2 vols. Paris: Hermès. Creissels, Denis, Gerrit Dimmendaal, Zygmunt Frajzyngier \& Chista König. 2008. Africa as a morphosyntactic area. In Bernd Heine \& Derek Nurse (eds.) A linguistic geography of Africa, 86-150. Cambridge: Cambridge University Press.

Demeke, Girma. 2001. N-final relative clauses: the Amharic case. Studia Linguistica 55(2). 192-216.

Dik, Simon. 1997. The theory of functional grammar. Berlin: Mouton de Gruyter.

Dimmendaal, Gerrit. 1983. The Turkana language. Dordrecht: Foris.

Doke, Clement. 1954. The Southern Bantu languages. London: Oxford University Press.

Downing, Bruce. 1978. Some universals of relative clause structure. In Joseph Greenberg, Charles Ferguson \& Edith Moravcsik (eds.), Universals of human language, Vol. 4, 375418. Stanford: Stanford University Press.

Downing, Laura, Annie Rialland, Jean-Marc Beltzung, Sophie Manus, Cédric Patin \& Kristina Riedel. (eds.). 2010. Papers from the workshop on Bantu relative clauses. Berlin: ZAS.

Dryer, Matthew. 2005. Order of relative clause and noun. In Martin Haspelmath, Matthew Dryer, David Gil \& Bernard Comrie (eds.), The atlas of language structures, 366-369. Oxford: Oxford University Press.

Dryer, Matthew. 2007. Word Order. In Timothy Shopen (ed.), Language typology and syntactic description. 3 vols. 2nd edn. Vol. 1, 61-131. Cambridge: Cambridge University Press. 
Fabb, Nigel. 1999. Relative Clauses. In Keith Brown \& Jul Miller (eds.), Concise encyclopedia of grammatical categories, 319-324. Oxford: Elsevier.

Ferguson, Charles. 1970. The Ethiopian Language Area. The Journal of Ethiopian Studies 8(2). 67-80.

Ferguson, Charles. 1976. The Ethiopian Language Area. In Marvin Bender, J. Donald Bowen, Robert Cooper \& Charles Ferguson (eds.), Language in Ethiopia, 63-76. London: Oxford University Press.

Genetti, Carol. 2007. A grammar of Dolakha Newar. Berlin \& New York: Mouton de Gruyter. Givón, Talmy. 1971. Historical syntax and synchronic morphology: an archaeologist's field trip. Proceedings of the seventh regional meeting of Chicago Linguistics Society, 394-415.

Greenberg, Joseph. 1959. Africa as a linguistic area. In William Bascom \& Melville Herskovitz. (eds.), Continuity and change in African cultures, 15-27. Chicago: Chicago University Press.

Grosu, Alexander. 2002. Strange relatives at the interface of two millenia. Glot International 6(6). 145-167.

Hayward, Dick. 1984. The Arbore language: a first investigation (including a vocabulary). Hamburg: Helmut Buske Verlag.

Hayward, Richard. 1978. Bayso revisited: some preliminary linguistic observations -- I. Bulletin of the School of Oriental and African Studies 41(3). 539-570.

Hayward, Richard. 1979. Bayso revisited: some preliminary linguistic observations -- II. Bulletin of the School of Oriental and African Studies 42(1). 101-132.

Hayward, Richard. 1993. The Wolaytta language. Heidelberg: Carl Winter.

Hayward, Richard. 2000. Afroasiatic. In Bernd Heine and Derek Nurse (eds.), African languages: an introduction, 74-98. Cambridge: Cambridge University Press.

Hayward, Richard. 2003. Omotic: the "empty quarter" of Afroasiatic linguistics. In Jacqueline Lecarme (ed.), Research in Afroasiatic grammar II: selected papers from the fifth conference on Afroasiatic languages, Paris 2000, 241-261. Amsterdam \& Philadelphia: John Benjamins.

Heine, Bernd. 1975. Language typology and convergence areas in Africa. Linguistics 144. 27 47.

Henderson, Brent. 2007. The syntax of agreement in Bantu relatives. In Frederick Hoyt, Nikki Seifert, Alexandra Teodorescu \& Jessica White (eds.), Texas Linguistics Society 9: Morphosyntax of Underrepresented Languages, 167-184. Austin: University Texas.

Herring, Susan. 1991. Nominalization, relativization and attribution in Lotha, Angami and Burmese. Linguistics of the Tibeto-Burman Area, 14(1). 55-72.

Hetzron, Robert. 1972. Ethiopian Semitic studies in classification. Manchester: Manchester University Press. 
Hieda, Osamu. 1998. A sketch of Koegu grammar: towards reconstructing Proto-Southeastern Surmic. In Gerrit Dimmendaal \& Marco Last (eds.), Surmic Languages and Cultures, 345373. Köln: Rüdiger Köppe Verlag.

Huber, Brigitte. 2003. Relative clauses in Kyirong Tibetan. Linguistics of the Tibeto-Burman Area, 26(1). 1-14.

Hudson, Grover. 1997. Amharic and Argobba, In Robert Hetzron (ed.), The Semitic languages, 457-485. London: Routledge.

Jaggar, Philip. 1998. Relative clauses in Hausa: where morphosyntax and semantics meet. Studies in African Linguistics, 27(2). 199-238.

Kazuhiro, Kawachi. 2007. A grammar of Sidaama (Sidamo), a Cushitic language of Ethiopia. New York: State University of New York doctoral dissertation.

Keenan, Edward 1985. Relative clauses. In Timothy Shopen (ed.), Language typology and syntactic description, Vol. 2, 141-170. Cambridge: Cambridge University Press.

Keenan, Edward \& Bernard Comrie. 1977. Noun phrase accessibility and universal grammar. Linguistic Inquiry 8(1). 63-99.

Keenan, Edward \& Bernard Comrie. 1979. Data on the noun phrase accessibility hierarchy. Language 55. 333-351.

Kogan, Leonid. 1997. Tigrinya. In Robert Hetzron (ed.), The Semitic languages, 424-445. London: Routledge.

Kornfilt, Jaklin. 1997. Turkish. London \& New York: Routledge.

Kroeger, Paul. 2004. Analyzing syntax: a lexical-functional approach. Cambridge: Cambridge University Press.

Kroeger, Paul. 2005. Analyzing grammar: an introduction. Cambridge: Cambridge University Press.

Kuteva, Tania \& Bernard Comrie. 2006. The typology of relative clause formation in African languages. In F. K. Erhard Voeltz (ed.), Studies in African linguistic typology, 209-228. Amsterdam \& Philadelphia: John Benjamins.

Lacroix, René. 2009. Description du dialecte laze d'Arhavi (caucasique du sud, Turquie). Lyon: Université Lumière Lyon II doctoral dissertation.

Lamberti, Marcello \& Roberto Sottile. 1997. Wolaytta Language. Cologne: Rudinger Koppe Verlag.

Lawal, Nike. 1987. Yoruba relativisation and the continuous segment principle. Studies in African Linguistics 18(1). 67-79.

Lefebvre, Claire \& Pieter Muysken. 1988. Mixed categories: nominalizations in Quechua. Dordrecht, Bonston \& London: Kluwer.

Lehmann, Christian. 1986. On the typology of relative clauses. Linguistics 24(4). 663-680.

Lehmann, Christian. 2003. Relative clauses. In William Frawley (ed.), International encyclopedia of linguistic, Vol. 3, 460-461. Oxford: Oxford University Press. 
Leslau, Wolf. 1945. The influence of Cushitic on the Semitic languages of Ethiopia: a problem of substratum. Word 1(1). 59-82.

Leslau, Wolf. 1952. The influence of Sidamo on the Ethiopic languages of Gurage. Language 28(1). 63-81.

Leslau, Wolf. 1959. A preliminary description of Argobba. Annales d'Ethiopie 3. 251-273.

Leslau, Wolf. 1995. Reference Grammar of Amharic. Wiesbaden: Harrassowitz.

Letsholo, Rose. 2009. The "forgotten" structure of Ikalanga relatives. Studies in African Linguistics 38(2). 131-154.

Lewis, Paul. (ed.). 2009. Ethnologue: languages of the world. 16th edn. Dallas, Texas: SIL International.

Little, Greta. 1974. Syntactic evidence of language contact: Cushitic influence in Amharic. In Roger Shuy \& Charles-James Bailey (eds.), Towards tomorrow's linguistics, 267-275. Washingon D.C.: Georgetown University Press.

Lusted, Marie. 1976. Anywa. In Lionel Bender (ed.), The Non-Semitic languages of Ethiopia, 495-512. East Lansing: African Studies Center, Michigan State University.

Lyth, Richard. 1971. The Murle language: grammar and vocabulary. Khartoum: University of Khartoum.

Mallinson, Graham \& Barry Blake. 1981. Language typology: cross-lingusitic studies in syntax. Amsterdam, New York \& Oxford: North-Holland Publishing Company.

Mason, John. 1996. Tigrinya grammar. Trenton: Red See Press.

Matsumura, Kazuto. 1981. Mari (Cheremis) relative clauses. Working Papers in Linguistics, 81. 45-55.

Musa, Abuzeinab, Charlotte Wedekind \& Klaus Wedekind. 2007. A learner's grammar of Beja (East Sudan). Köln: Rüdiger Köppe Verlag.

Mutaka, Ngessimo. 2000. An introduction to African linguistics. Muenchen: Lincom Europa.

Nedjalkov, Igor. 1997. Evenki. London \& New York: Routledge.

Overfelt, Jason. 2009. The syntax of relative clause constructions in Tigrinya. West Lafayette, IN: Purdue University master dissertation.

Owens, Jonathan. 1985. A grammar of Harar Oromo (Northeastern Ethiopia) including a text and a glossary. Hamburg : Helmut Buske.

Oyharçabal, Bernard. 2003. Relatives. In José Hualde \& Jon Ortiz de Urbina (eds.), $A$ grammar of Basque, 762-822. Berlin \& New York: Mouton de Gruyter.

Palmer, Frank. 1961. Relative clauses in Tigre. Word 17. 23-33.

Palmer, Frank. 1962. Relative clauses in Tigrinya. Journal of Semitic Studies 7. 36-43.

Pandharipande, Rajeshwari. 2003. Marathi. In George Cardona \& Dhanesh Jain (eds.), The Indo-Aryan languages, 698-728. London \& New York: Routledge.

Rawda, Siraj. 2003. Relativization in Silt'i. Addis Ababa: Addis Ababa University doctoral dissertation. 
Rose, Sharon. 2007. Chaha (Gurage) morphology. In Alan Kaye (ed.), Morphologies of Asia and Africa, 403-427. Winona Lake, IN: Eisenbraums.

Savà, Graziano. 2005. A grammar of Ts'amakko. Cologne: Rüdiger Köppe.

Schneider-Blume, Gertrud. 2007. A Grammar of Alaaba. A Highland East Cushitic language of. Ethiopia. Cologne: Rüdiger Köppe.

Schwartz, Arthur. 1971. General aspects of relative clause formation. Working Papers in Language Universals 6. 139-171.

Seyoum, Mulugeta. 2008. A grammar of Dime. Utrecht: LOT.

Simeone-Senelle, Marie-Claude. 2008. Les relatives en afar. Unpublished manuscript. Paris: Université Paris-Diderot - Paris VII.

Sohn, Ho-Min. 1999. The Korean language. Cambridge: Cambridge University Press.

Song, Jae Jung. 2001. Linguistic typology: morphology and syntax. Harlow: Pearson Education.

Sridhar, Shikaripur. 1990. Kannada. London \& New York: Routledge.

Thomason, Sarah. 2001. Language contact. Edinburgh: Edinburgh University Press.

Thomason, Sarah \& Terrence Kaufman. 1988. Language contact, creolization, and genetic linguistics. Berkeley: University of California Press.

Thompson, David. 1976. Nera. In Lionel Bender (ed.), The Non-Semitic languages of Ethiopia, 484-494. East Lansing: African Studies Center, Michigan State University.

Tosco, Mauro. 1994. The historical syntax of East Cushitic: a first sketch. In Thomas Bearth, Wilhelm Möhlig, Beat Sottas \& Edgar Suter (eds.), Perspektiven afrikanistischer Forschung. Beiträge zur Linguistik, Ethnologie, Geschichte, Philosophie und Literatur / X. Afrikanistentag (Zürich, 23-25 September 1993), 415-440. Köln: Rüdiger Köppe.

Tosco, Mauro. 2000. Is there an Ethiopian Language Area? Anthropological Linguistics 42:329-365.

Tosco, Mauro. 2003. Cushitic and Omotic overview. In Lionel Bender, David Appleyard, \& Gábor Takács (eds.), Afrasian: selected comparative/historical papers in memory of Igor M. Diakonoff, 87-92. München: Lincom Europa.

Treis, Yvonne. 2008. Relativization in Kambaata (Cushitic). In Zygmunt Frajzyngier \& Erin Shay (eds.), Interaction of morphology and syntax: case studies in Afroasiatic, 161-206. Amsterdam \& Philadelphia: John Benjamins.

Triulzi, Dafallah \& Lionel Bender. 1976. Berta. In Lionel Bender (ed.), The Non-Semitic languages of Ethiopia, 513-532. East Lansing: African Studies Center, Michigan State University.

Tucker, Archibald. \& Margaret Bryan. 1966. Linguistic analyses: the Non-Bantu languages of North-Eastern Africa. Oxford: Oxford University Press.

Unseth, Peter. 1989. Sketch of Majang Syntax. In Lionel Bender (ed.), Topics in NiloSaharan Linguistics, 97-127. Hamburg: Helmut Buske.

Vries, Mark de. 2001. Patterns of relative clauses. Linguistics in Netherlands 18. 231-243. 
Vries, Mark de. 2002. The syntax of relativization. Utrecht: LOT.

Vries, Mark de. 2005. The fall and rise of universals on relativization. Journal of Universal Language 6(1). 125-157.

Wagner, Ewald. 1997. Harari. In Robert Hetzron (ed.), The Semitic languages, 486-508. London: Routledge.

Wakasa, Motomichi. 2008. A descriptive study of the Modern Wolaytta language. Tokyo: The University of Tokyo doctoral dissertation.

Watters, John. 2000. Syntax. In Bernd Heine and Derek Nurse (eds.), African languages: an introduction, 194-230. Cambridge: Cambridge University Press.

Wedekind, Klaus., Charlotte Wedekind \& Abuzeinab Musa. 2008. Beja pedagogical grammar. Unpublished manuscript. Cologne University, Institut fuer Afrikanistik. http://www.afrikanistik-online.de/archiv/2008/1283.

Welmers, William. 1973. African language structures. Berkeley: University of California Press.

Wetter, Andreas. 2010. The relative clause in Argobba and its functions. Talking given at Seminar für Afrikawissenschaften, Humboldt-Universität zu Berlin, 9, February 2010.

Whaley, Lindsay. 1997. Introduction to typology: the unity and diversity of language. London: SAGE Publications.

Will, Hans-Georg. 1989. Sketch of Me'en syntax. In Lionel Bender (rd.), Topics in NiloSaharan linguistics, 129-150. Hamburg: Helmut Buske.

Williamson, Kay. 1965. A grammar of the Kolokuma dialect of Ijo. Cambridge: Cambridge University Press.

Winford, Donald. 2003. An introduction to contact linguistics. Oxford: Blackwell.

Woldemariam, Hirut. 2004. A grammar of Haro with comparative notes on the Ometo linguistic group. Addis Ababa: Addis Ababa University doctoral dissertation.

$\mathrm{Wu}$, Tong. 2011. The syntax of prenominal relative clauses: a typological study. Linguistic Typology, 15(3), 569-623.

Zaborski, Andrzej. 1991. Ethiopian Language Subareas. In Stanislaw Pilaszewicz \& Eugeniusz Rzewuski (eds.), Unwritten testimonies of the African past, 123-134. Warszaw: Wydawnictwa Uniwesytetu Warszawskiego.

Zaborski, Andrzej. 2003. Ethiopian Language macroarea. Sprawozdania z Posiedzeń Komisji Naukowych. Oddziału PAN w Krakowie 45(2). 60-64.

Zaborski, Andrzej. 2010. Language Subareas in Ethiopia reconsidered. Journal Lingua Posnaniensis 52(2). 99-110.

Zeller, Jochen. 2004. Relative clause formation in the Bantu languages of South Africa. Southern African Linguistics and Applied Language Studies 22 (1\&2). 75-93. 


\section{Appendix: Languages discussed}

\author{
Afar (Cushitic) \\ Alaba-K'abeena (Cushitic) \\ Amharic (Semitic) \\ Anuak (Nilo-Saharan) \\ Arabic (Semitic) \\ Arbore (Cushitic) \\ Argobba (Semitic) \\ Babungo (Niger-Congo) \\ Baiso (Cushitic) \\ Basque (Isolate) \\ Bedawiyet (Cushitic) \\ Berta (Nilo-Saharan) \\ Bilen (Cushitic) \\ Burmese (Sino-Tibetan) \\ Chaha Sebat Bet Gurage (Semitic) \\ Cuzco Quechua (Quechan) \\ Dime (Omotic) \\ Dirasha (Cushitic) \\ Dizi (Omotic) \\ Dolakha Newar (Sino-Tibetan) \\ Efik (Niger-Congo) \\ Evenki (Altaic) \\ Gamo (Omotic) \\ Gumuz (Nilo-Saharan) \\ Harar Oromo (Cushitic) \\ Harari (Semitic) \\ Haro (Omotic) \\ Hausa (Chadic) \\ Ijo (Niger-Congo) \\ Inor (Semitic) \\ Kambaata (Cushitic) \\ Kannada (Dravidian) \\ Kanuri (Nilo-Saharan)
}

Koszime (Niger-Congo)

Khoekhoe (Khoisan)

Korean (Isolate)

Kunama (Nilo-Saharan)

Kwegu (Nilo-Saharan)

Kyirong Tibetan (Sino-Tibetan)

Laze (Kartvelian)

Majang (Nilo-Saharan)

Male (Omotic)

Mandarin (Sino-Tibetan)

Marathi (Indo-European)

Mari (Uralic)

Me'en (Nilo-Saharan)

Mina (Chadic)

Murle (Nilo-Saharan)

Nara (Nilo-Saharan)

Ngemba (Niger-Congo)

Nuer (Nilo-Saharan)

Qimant (Cushitic)

Saho (Cushitic)

Sidamo (Cushitic)

Silt'e (Semitic)

Suri (Nilo-Saharan)

Tigré (Semitic)

Tigrigna (Semitic)

Tsamai (Cushitic)

Tswana (Niger-Congo)

Turkana (Nilo-Saharan)

Turkish (Altaic)

Wolaytta (Omotic)

Xamtanga (Cushitic)

Yoruba (Niger-Congo)

Zaysete (Omotic) 
wu.tong.linguistics@gmail.com

Accepted: 27 August 2012

College of Foreign Langugages

Revisions: 11 November 1012

Nankai University

94 Weijin Street

Tianjin

PR China 